\title{
THE PRAGMATICS OF THE SPOKEN WORD (BASED ON THE POLITICAL MEDIADISCOURSE OF THE BRITISH PRESS)
}

The sphere of colloquial vocabulary functioning is constantly expanding, which can be seen on the pages of such serious British media publications as The Times and The Guardian. Currently, stylistically lowered lexemes are used not only in interviews with stars, film reviews and comments about celebrities' personal life, but also in articles covering political events. The percentage frequency of such abuse is not high, these contexts are vivid examples of the democratization process of speech norms. At the same time, the most interesting are cases where conversational vocabulary is used in the direct quotation of high-ranking officials' words. Political discourse is a representative of the elite type of speech culture, the functioning of conversational lexemes in the context of political discourse determines the divergence of pragmatic characteristics of these lexemes and context pragmatists and contributes to additional contextual meanings fluctuations. In this article, the main pragmatic functions of stylistically lowered words in officials' speech, and pragmatic bases of contextual meanings playing out in the author's speech of the mediatext are highlighted. In the case of a lexeme functioning with the direct implementation of its pragmatics in the official's speech, we are talking about a single-leveled axiological structure of the context, in the case of acquiring additional contextual meanings in the context of the article, we are talking about the ambivalent or two-leveled axiological structure of the context. In general, the following pragmatic functions of colloquial vocabulary are singled out in this article: evaluation expression, evaluation intensity modification, irony explication, hedonic presentation of the material, the creation of a trusting atmosphere of communication with the audience.

Keywords: pragmatics, colloquial vocabulary, one-leveled axiological context structure, ambivalent axiological context structure, evaluation.

\section{О.Б. Солдатова}

Барнаульский юридический институт МВД России, Барнаул, Российская Федерация
Получена: 20.01.2018

Принята: 13.02.2018

Опубликована: 30.06.2018

\section{ПРАГМАТИКА РАЗГОВОРНОГО СЛОВА (НА МАТЕРИАЛЕ ПОЛИТИЧЕСКОГО МЕДИАДИСКУРСА БРИТАНСКОЙ ПРЕССЫ)}

Сфера функционирования разговорной лексики постоянно расширяется, что можно наблюдать на страницах таких серьезных британских медиа изданий, как The Times и The Guardian. В настоящее время стилистически сниженные лексемы используются не только в интервью со звездами, обзорах фильмов и комментариях по поводу личной жизни знаменитостей, но и в статьях, освещающих политические события. Процентная частотность подобного речеупотребления не высока, данные контексты являются яркими примерами демократизации речевых норм. При этом 
наибольший интерес представляют случаи приведения разговорной лексики в рамках прямого цитирования слов высокопоставленных официальных лиц. Политический дискурс является репрезентантом элитарного типа речевой культуры, функционирование разговорных лексем в контексте политического дискурса детерминирует дивергенцию прагматических характеристик указанных лексем и прагматики контекста и способствует флуктуации дополнительных контекстуальных смыслов. В данной статье выделяются основные прагматические функции стилистически сниженных лексем в речи официального лица и прагматические базисы обыгрывания контекстуальных смыслов в речи автора медиатекста. В случае функционирования разговорной лексемы с прямой реализацией ее прагматики в речи чиновника мы говорим об одноуровневой аксиологической структуре контекста, в случае приобретения дополнительных контекстуальных смыслов в контексте статьи речь идет об амбивалентной или двухуровневой аксиологической структуре контекста. В целом в данной статье выделяются следующие прагматические функции разговорной лексики: выражение оценки, модификация интенсивности оценки, экспликации иронии, гедонистическая презентация материала, создание доверительной атмосферы общения с аудиторией.

Ключевые слова: прагматика, разговорная лексика, одноуровневая аксиологическая структура контекста, амбивалентная аксиологическая структура контекста, оценка.

English collocations, being a distinctive feature of informal communication according to the pragmatic information of word meanings, are increasingly often used in various types of discourse, including pages of such serious British newspapers as The Times and The Guardian, as evidenced by the analysis of more than 5,000 mediacontexts of colloquially-labeled lexical units functioning. The presence of colloquial marking of a word is revealed at the level of a lexeme definition represented by the English-English explanatory dictionary [1] when there are markers "(very) informal", “(mainly) spoken", "slang", "vulgar" in the definition.

Publicistic style, political discourse and conversationalism in general are relevant scientific directions, and there are a great number of publications covering these topics. Within the framework of this study, we take into consideration the works on integration of rhetoric and style culture [2], theory of types of speech cultures [3, 4], axiological linguistics [5, 6] and medialinguistics [7, 8].

The language of the media is characterized by wealth, variability, symbolism, manipulativeness, determined by the need to express evaluation and to form public views and attitudes to the events covered. Political mediatexts, whose goal is agitation, propaganda and audience perception influence, must invariably have all of the above mentioned characteristics. In connection with this, the contexts are rich in brightness, imagery, appraisal and consistent tendency of persuasion, one of the means to achieve these distinctive features is use of colloquial vocabulary. It should be noted that the frequency of using stylistically marked lexemes depends on a rubric and section of a newspaper. Thus, spoken vocabulary is often used in movies and performances reviews, in articles on stars, especially musicians, in some cases in the form of quoting the words of respondents. Political commentaries and news, on the contrary, are characterized by the use of stylistically neutral and bookish lexicon.

Based on the scope of the literary language, some scholars distinguish the following types of speech cultures: elite, medium-literary, literary-colloquial, familiar [3, 9]. Political discourse refers to the type of elite speech cultures, and therefore the divergence of pragmatic characteristics of conversationality and pragmatics of the elite type of the context realizes the spectrum of certain func- 
tions. In this regard, I.A. Ivanchuk describes colloquialism as a rhetorical category, combining the desire for expression as a means of enhancing the impact on the addressee and the need to respect the ethical-aesthetic norms of communication [9].

The purposes of this study are to identify the pragmatic functions of informal vocabulary usage in the political mediatexts of the British press and to define levels of axiological context structure understanding. As the main methods in the work, scientific modeling, lexical, semantic, contextual and linguistic types of the analysis are used. Within the framework of the article, the following pragmatic functions of conversationality usage in political discourse are distinguished: 1) explication of expressiveness, 2) creation of the atmosphere of trust and closeness with the addressee; 3) evaluation expression; 4) evaluation intensity modification: 5) implication of irony; 6) hedonic presentation of information. In a number of cases, several functions are implemented in a separate context.

The pragmatics of creating an image of a confidential conversation with the audience can be seen in the examples below $(1,2)$ :

(1) Jones emerged to a euphoric reception just before $10 \mathrm{pm}$ local time. "Folks, I gotta tell you, I think that I have been waiting all my life and now I just don't know what the hell to say," he said, beginning a 10-minute speech. "I have always believed that the people of Alabama had more in common than what would divide us" [10].

The welcome speech of Doug Jones after his election abounds with colloquialisms (folks, gotta, what the hell) that marks his emotional excitement and desire to seem more direct in communication, to be closer to his voters. Frequently being a means of expressing evaluation, the colloquiality determines the axiological structure of the context, which is the result of the interaction of social information embedded in the text, the author's interpretation of reality and the value picture of the world of the individual recipient (Marjanchik, 2013: 2). The axiological structure of the official's speech is pragmatically aimed at 1) demonstrating communication with the audience at the same level, 2) expressing a positive attitude towards voters, which implicates a positive assessment of the situation.

(2) At the factory, Kim complimented workers for manufacturing the tires for the nine-axle missile truck without relying on imported equipment. He also called for efforts to raise production to "satisfy the daily-increasing needs in developing the country's economy and beefing up national defence capabilities," the North's official news agency reported [11].

Spoken phrasal verb beef up 'to increase or improve something, or to make it more interesting', functioning in the speech of the North Korean president in conversation with employees in the workplace, contributes to the creation of the atmosphere of a friendly conversation, since the goal of the president's addressing people in this situation is to express satisfaction with the work done and diligence of the workers of this enterprise. So, pragmatics of this context coincides with the one of the previous example. 
The same functions are realized in the next example. But here we come across with one more pragmatic characteristics, formation of evaluation intensity:

(3) Trump even made reference to the former CNN contributor Jeffrey Lord, who was fired for tweeting the Nazi salute "Sieg Heil" at a liberal activist. "Poor Jeffrey," the president said. "I guess he was getting a little bit fed up and was probably fighting back too hard and they said, 'We gotta get out of here," [12].

In this mono-leveled axiological context structure the use of colloquialisms in the speech of the American president is also aimed at establishing a trusting atmosphere of communication with the audience, in addition, colloquially-labeled lexical units weaken the intensity of the negative evaluation of Jeffrey Lord. It is the colloquial stylistic marking of the used lexemes that determines the creation of the subtext "we are all human beings and can make mistakes", implicating leniency and understanding.

It should be noted that we treat an axiological context structure as mono/ single-leveled when the evaluation can be understood in the only way. If the evaluation within a quotation is either meliorative or pejorative but on the level of the context on the whole it acquires the opposite evaluation sign or implies some additional information hints, we speak about two-leveled axiological structure of the context, as it can be seen in the following contexts $(4,5,6,7)$ :

(4) Tillerson could be tougher, Trump said. He did not elaborate on what that meant. It was reported this week that in a session with Trump's national security team and cabinet officials at the Pentagon this summer, Tillerson openly criticized the president and called him a "fucking moron" [13].

The usage of the vulgarism moron 'an insulting word for someone who behaves in a stupid way', intensified by another vulgarism fucking 'an extremely offensive expression used for emphasizing what you are saying, especially to show anger', within the words of the US Secretary of State referring to the president of the country expresses highly intensive negative evaluation and irritation of a highranking official with the actions of the American leader. The axiological structure of the analyzed example determines the presence of a binary valuation opposition: 1) negative expressive assessment of the actions and personality of the American president, openly expressed by Rex Tillerson; 2) negative evaluation of the informal nature of the official's statement by the author, as implied by the separate quoting of colloquial units. It should be noted that the frequency of vulgarisms functioning, as the most stylistically lowed representative of conversationality, is not high, as a rule, these colloquial explanations function in a political mediacontext in the form of direct quoting of officials' words with the purpose of creating expressiveness and intensive assessment of the situation covered.

(5) On Saturday Trump said again that the reports of the "moron" remark, which reportedly made him furious and led to staff efforts to control the controversy, were "fake news" [13].

Prepositional use of vulgarism moron to lexeme remark within D. Tramp's direct quotation is intended to elucidate the high-intensity pejorative assessment of 
the situation by the American leader, his emotional resentment over the recurring questions from journalists and the desire to stop further discussion of this problem, which the president defines as "fake news". The intensity of the negative evaluation, which is caused by the repeated discussion of the situation (again), is marked with the word furious 'extremely angry'. The citation of separated lexemes in this context, in our opinion, testifies to the author's ironic attitude to the reaction of the American president, which determines the creation of an ambivalent assessment at the context level: the author is distrustful of the official's words. Thus, in this example, there is a two-leveled axiological context structure: 1) the president's negative assessment of the situation, 2) the author's ironic attitude towards the indignation of the president and negative evaluation of the president's behavior. This duality leads to the realization of such pragmatic functions as 1) the expression of the evaluation, 2) the explication of irony, 3) the hedonic presentation of information.

(6) Trump used Tuesday's event to portray himself as the victim of events in Charlottesville, branding journalists who "do not like our country" as the true source of division in America. He also accused the "crooked media" of "trying to take away our history and our heritage" and read out previous statements that he said condemned hatred, bigotry and violence [14].

One of the means of representing propaganda against the media in the speech of the American leader in this context is the functioning of the colloquial lexeme crooked 'dishonest and likely to do illegal things, especially in order to get money' in the quoting D. Trump's words context of expressing emotions and pejorative assessment of media resources attacks aimed at him, as well as creating a trusting atmosphere of communication with the auditory, as the president demonstrates openness and freely shares his opinion. Nevertheless, the author of the article implicitly expresses his point of view, which does not coincide with the opinion of the American president, by means of giving short quotes taken from the direct speech of D. Trump. Such a reduction of the words of the official person determines the creation of an ambivalent assessment at the context level: the negative evaluation of the words of the American leader is negatively assessed by the author, which in the analyzed context results in the explication of the negative evaluation of D. Trump's personality and actions and the positive evaluation of the media. This statement is confirmed with the functioning of separate lexemes of the first sentence: thus, according to the presentation of the article author, the president used the situation in his own interests ("used [...] to portray himself as the victim"), presenting journalists as people who "do not like our country" and are "the true source of division in America". In the second sentence of the proposed context the American leader continues to expose a negative assessment of the media actions: accused [...] of "trying to take away our history and our heritage", condemned hatred, bigotry and violence.

(7) Conservative pundit Meghan McCain, the daughter of John McCain, wrote on Twitter: "Suck it, Bannon" [15]. 
Vulgarism suck it 'used for saying that someone has to accept a difficult or unpleasant situation even if they do not want to', functioning in the statement of a conservative party expert, a high-ranking official's daughter, is aimed at expressing two intense diametrically opposite appraisal explications: a positive evaluation of the victory of Doug Jones and a negative assessment of the individuality and political program of Steve Bannon. The low stylistic marking of the expression demonstrates the franticness of the speaker's emotions, but at the same time, this is the very stylistic decrease of the lexeme, related to the divergence with the pragmatic characteristics of political discourse as an elitist type of speech culture, which forces the author of the article to use quotation marks, referring to the quotation of an official's words and showing disapproval of the official's using it. It makes the axiological structure of this context two-leveled.

Thus, when used in a political mediadiscourse, colloquial lexemes realize a spectrum of pragmatic functions: in the quoted speech of an official conversation expresses emotiveness, evaluation, and creates an atmosphere of direct and friendly communication. In this case, the recipient has to deal with a mono/ single-leveled axiological structure of the text and has the opportunity to form their attitude to the cited words and the events covered. Since the texts of the mass media are aimed not only at informing the society, but also modeling its relation to the events, in a number of cases the stylistically marked lexical units contribute to the realization of other pragmatic functions, namely: the discord between the conversationality and the political discourse as a representative of the elitist type of speech cultures determines the fluctuation of the two-leveled axiological structure of the context, which determines the possibility of realizing such pragmatics as hedonic presentation of information, author's expression of irony and sarcasm, creation of assessment on the context level, frequently characterized by diametrically opposite sign regarding quoted official's words.

The study of functioning of colloquial words in political mediatexts allows us to obtain new data on the realization of a lexeme axiological potential, its connotative meanings and the variation of contextual meanings, caused by the conversationality and pragmatic information of a word meaning.

\section{References}

1. Rundell M. Macmillan English Dictionary for advanced learners. Oxford, 2002.

2. Vinogradov S.I. Normativnyi i kommunikativno-pragmaticheskii aspekty kul'tury rechi [Normative and communicative-pragmatic aspects of the culture of speech]. Kul'tura russkoi rechi i effektivnost' obshcheniia. Moscow, 1996, pp. 121-152.

3. Tolstoi N.I. Iazyk i narodnaia kul'tura. Ocherki po slavianskoi mifologii i etnolingvistike [Language and folk culture. Essays on Slavic mythology and ethnolinguistics]. Moscow, 1995.

4. Gol'din V.E., Sirotinina O.B. Vnutrinatsional'nye rechevye kul'tury i ikh vzaimodeistvie [Intranational speech cultures and their interaction]. Voprosy stilistiki. Problemy kul'tury rechi [Questions of stylistics. Problems of the culture of speech]. Vol. 25, Saratov, 1993, pp. 9-19. 
5. Mar'ianchik V.A. Aksiologicheskaia struktura media-politicheskogo teksta (lingvostilisticheskii aspekt) [The axiological structure of the media-political text (linguostylistic aspect)]. Ph.D. thesis. Arkhangelsk, 2013.

6. Bugaeva O.B. Aksiologicheskii potentsial razgovornogo slova i ego realizatsiia $\mathrm{v}$ britanskoi presse [Axiological potential of the spoken word and its realization in the British press]. Ph.D. thesis. Barnaul, 2011.

7. Solganik G.Ia. K opredeleniiu poniatii "tekst" i "mediatekst" [To the definition of the concepts "text" and "mediatext"]. The Journal Vestnik Moskovskogo Universiteta. Seriia 10: Zhurnalistika, 2005, no. 2, pp. 7-16.

8. Shmeleva T.V. Mediatizatsiia kak fenomen sovremennoi kul'tury i ob'ekt issledovaniia [Mediatization as a phenomenon of modern culture and the object of research]. Vestnik of Yaroslav the Wise Novgorod State University, 2015, no. 7 (90), pp. 145-148.

9. Ivanchuk I.A. Ritoricheskaia kategoriia razgovornost' v publichnoi rechi nositelei elitarnogo tipa rechevoi kul'tury: esteticheskii aspekt [Rhetorical category of conversationality in public speech of the bearers of the elite type of speech culture: aesthetic aspect]. Vestnik Saratovskogo sotsial'no-ekonomicheskogo universiteta, 2003, no. 6, pp. 141-149.

10. Jacobs B., Smith D. Alabama election: Democrates defeat Roy Moore, Dealing huge blow to Trump. The Guardian, 2017, December, 13.

11. Collins P. Risk of war with North Korea grows each day, Says Trump's Security Adviser. The Guardian, 2017, December, 3.

12. Siddique H., Laughland O. Charlottesville: United Nations warns US over 'alarming' rasism. The Guardian, 2017, August, 24.

13. Martin J. Trump says 'Only one thing will work' with nuclear armed North Korea. The Guardian, 2017, October, 7.

14. Smith D. Trump paints himself as the real victim of Charlotesville in angry speech. The Guardian, 2017, August, 23.

15. Jacobs B. As democrats rejoice in Roy Moore loss, Republicans look for someone to blame. The Guardian, 2017, December, 14.

\section{Список литературы}

1. Rundell M. Macmillan English Dictionary for Advanced Learners. - Oxford: Macmillan Publishers Limited, 2002.

2. Виноградов С.И. Нормативный и коммуникативно-прагматический аспекты культуры речи // Культура русской речи и эффективность общения. - М., 1996. С. $121-152$.

3. Толстой Н.И. Язык и народная культура. Очерки по славянской мифологии и этнолингвистике. - М., 1995.

4. Гольдин В.Е., Сиротинина О.Б. Внутринациональные речевые культуры и их взаимодействие // Вопросы стилистики. Проблемы культуры речи. Вып. 25. - Саратов, 1993. - С. 9-19.

5. Марьянчик В.А. Аксиологическая структура медиа-политического текста (лингвостилистический аспект): автореф. дис. ... д-ра филол. наук. - Архангельск, 2013.

6. Бугаева О.Б. Аксиологический потенциал разговорного слова и его реализация в британской прессе: автореф. дис. ... канд. наук. - Барнаул, 2011. 
7. Солганик Г.Я. К определению понятий «текст» и «медиатекст» // Вестник Моск. ун-та. - Сер. 10: Журналистика - 2005. - № 2. - С. 7-16.

8. Шмелева Т.В. Медиатизация как феномен современной культуры и объект исследования // Вестник Новгород. гос. ун-та им. Ярослава Мудрого. - 2015. № 7 (90). - С. 145-148.

9. Иванчук И.А. Риторическая категория разговорность в публичной речи носителей элитарного типа речевой культуры: эстетический аспект // Вестник Саратов. социал.-экон. ун-та. - 2003. - № 6. - С. 141-149.

10. Jacobs B., Smith D. Alabama election: Democrates Defeat Roy Moore, Dealing Huge Blow to Trump // The Guardian. - 2017. - December, 13.

11. Collins P. Risk of War with North Korea Grows Each Day, Says Trump's Security Adviser // The Guardian. - 2017. - December, 3.

12. Siddique H., Laughland O. Charlottesville: United Nations Warns US over 'Alarming' Rasism // The Guardian. - 2017. - August, 24.

13. Martin J. Trump Says 'Only One Thing will Work' with Nuclear Armed North Korea // The Guardian. - 2017. - October, 7.

14. Smith D. Trump Paints himself as the Real Victim of Charlotesville in Angry Speech // The Guardian. - 2017. - August, 23.

15. Jacobs B. As Democrats Rejoice in Roy Moore Loss, Republicans Look for someone to Blame // The Guardian. - 2017. - December, 14.

\section{Сведения об авторе}

\section{СОЛДАТОВА Олеся Борисовна}

e-mail: bugaeva82@mail.ru

Кандидат филологических наук, Барнаульский юридический институт МВД России, научно-исследовательский и редакционноиздательский отдел, научный сотрудник (Барнаул, Российская Федерация)

\section{About the author}

\section{Olesya B. SOLDATOVA}

e-mail: bugaeva82@mail.ru

Candidate of Philological Sciences, Researcher, Research and Editorial and Publishing Department, Barnaul Law Institute of the Ministry of Internal Affairs of Russia (Barnaul, the Russian Federation) 